\title{
Acute and chronic toxicity of the benzodiazepine diazepam to the tropical crustacean Mysidopsis juniae
}

\author{
ALLYSON Q. DA SILVA, JEAMYLLE NILIN, SUSANA LOUREIRO \& \\ LETICIA V. COSTA-LOTUFO
}

\begin{abstract}
Pharmaceuticals occur in the environment due to their excessive consumption and the inefficiency of treatment plants to degrade, inactivate or remove them. Diazepam (DZP) stands out as the most consumed benzodiazepine, and induces sedative effects and reduces anxiety. Considering its potential appearance in several environmental compartments, the aim of the present study was to determine the effects of DZP under acute and chronic exposures on the mysid Mysidopsis juniae. Mortality was assessed using an acute toxicity test and $\mathrm{a} \mathrm{LC}_{50}$ of $3.7 \pm 0.5 \mathrm{mg} \cdot \mathrm{L}^{-1}$ was derived. The mass and length of the mysids was recorded in the chronic exposure to test for sublethal effects, and concentrations of 0.25 and $0.5 \mathrm{mg} \cdot \mathrm{L}^{-1}$ of DZP affected mysids length and dry weight, respectively. Although effect-inducing concentrations used in this study are above environmentally relevant levels, the present study adds value to the limited available data for DZP toxicity to marine organisms, and we have shown that $M$. juniae is the most sensitive marine crustacean species tested thus far.
\end{abstract}

Key words: emerging contaminants, mysids, sublethal effects, pharmaceuticals.

\section{INTRODUCTION}

The fate and toxicity of emerging contaminants to aquatic ecosystems has been receiving increasing attention, particularly due to limited knowledge about their environmental behavior and action on non-target organisms. Wastewater treatment plants are not effective at completely degrading emerging contaminants, leading to the potential contamination of aquatic ecosystems (Fent et al. 2006, Suárez et al. 2008). These chemicals have demonstrated a high capacity to resist abiotic or biotic degradation, which makes them persistent and harmful to the environment, and in some cases leads to microbial resistance (Redshaw et al. 2008).

Recently, the development of more sensitive analytical techniques has demonstrated the presence of emerging contaminants in environmental samples. Among those, pharmaceutical compounds have been detected in the range of $\mathrm{ng} \cdot \mathrm{L}^{-1}$ to $\mu \mathrm{g} \cdot \mathrm{L}^{-1}$ (Fent et al. 2006) in samples from surface waters (Kuster et al. 2009, López-Serna et al. 2012, Patrolecco et al. 2013), drinking water (Zuccato et. al. 2000), groundwater (Jones et al. 2001), effluent wastewater (Ven et al. 2004, Ferrer et al. 2010, Yuan et al. 2013), wetlands (Andreu et al. 2016) and seawater (RodríguezNavas et al. 2013).

Pharmaceuticals are designed to produce effects in determinate biological systems for which they are developed (Fent et al. 2006). However, these compounds are found outside of the systems for which they are developed, such as aquatic environments. Therefore, because they are capable of acting in biological 
systems it is necessary to understand the effects of pharmaceutical compounds in nontarget aquatic organisms. Although the ability to generate lethal effects on non-target organisms has already been reported through exposure to concentrations far from those encountered in water (Henry et al. 2004, Quinn et al. 2008, Kim et al. 2009), the identification of sublethal effects is more notable because they may be induced by concentrations close to those found in the environment (Fent et al. 2006).

The benzodiazepines are a class of pharmaceutical compounds with high consumption around the world. They are prescribed mainly to treat anxiety and combat seizures in humans and animals (Shephard 1986, Calisto \& Esteves 2009). Benzodiazepines are depressants of the central nervous system. The compounds act on GABA receptors by promoting the ability of chloride to permeate cells, which prevents repolarization and leads to the inhibition of potential dissipation and then neuronal inhibition (Mckernan et al. 2000). Diazepam is the most consumed compound in the group of benzodiazepines (Calisto \& Esteves 2009), and is one of the three anxiolytics most consumed in the world (INCB 2014). In Brazil, it is estimated that $0.5 \%$ of the population is dependent on this class of pharmaceuticals, and diazepam is the most extensively prescribed and consumed benzodiazepine in this country (OBID 2007).

The constant entry of contaminants of different classes into receiving water bodies makes it necessary to understand the interaction between these xenobiotics and biota. In this sense, ecotoxicological tests can evaluate the action of a xenobiotic on organisms and how their effects are manifested at various levels of structural organization (Costa et al. 2008). Usually these consist of standardized tests in which organisms that are representative of biota are exposed to high concentrations of the compound for a short amount of time or at low concentrations over a long period of time, providing acute and chronic toxicity data, respectively (Costa et al. 2008). Such assessments provide data for environmental agencies to establish permissible limits of chemical compounds in order to ensure the environmental quality of ecosystems.

Some animals, especially invertebrates, are being used as experimental models to assess the effects of anthropogenic discharge on aquatic ecosystems (Silva et al. 2017, Nilin et al. 2019). Among them, marine crustaceans have been studied to assess the impact of chemicals in estuarine and marine environments (Figueirêdo et al. 2015), as these compartments can become a final sink of effluents. Mysidopsis juniae (Mysidacea) is a species of microcrustacean that is important in trophic chains as it feeds on phytoplankton and other microcrustaceans (Domingues \& Bertoletti 2006) and is a food source for several fish species. This species has been used in ecotoxicological tests because of its ecological importance to the structure of the aquatic food web and its higher sensitivity to a wide range of xenobiotics than other test organisms (Verslycke et al. 2004, Bif et al. 2013, Gurgel et al. 2016, Silva et al. 2017, Nilin et al. 2019). In Brazil, the Brazilian Association of Technical Standards has standardized an acute toxicity test for M. juniae (ABNT 2011) and other studies have indicated that this species is a good candidate for chronic toxicity testing (Figueirêdo et al. 2016).

Therefore, the aim of the present study was to investigate the effects of diazepam on the survival and growth of the mysid M. juniae. We performed two tests: 1) an acute toxicity test to assess survival based on the standard from ABNT (2011) and 2) a chronic toxicity test, based on the protocol developed by Figueirêdo et al. 
(2016), where survival, weight and length were assessed.

\section{MATERIALS AND METHODS}

The drug Diazepam (anxiolytic drug, CAS No. 43914-5) was purchased from GERMED ${ }^{\circledR}$. Diazepam (DZP) was obtained as a commercial injectable solution (5mg. $\mathrm{mL}^{-1}$ ) and dilutions of $0.625,1.25$, 2.5 and $5 \mathrm{mg} \cdot \mathrm{L}^{-1}$ were made directly in seawater, but we did not use any solvents.

Mysidopsis juniae were cultured in the Laboratório de Ecotoxicologia Marinha at the Instituto de Ciências do Mar (LABOMAR). The culture was maintained under controlled conditions and kept in aquariums (10 L) with filtered natural seawater (filter $0.8 \mu \mathrm{m}$ ) and a gender proportion of 15 males to 45 females. Abiotic conditions were as follows: seawater salinity at 35; photoperiod of $12 \mathrm{~h}$ light/12h dark; temperature of $25 \pm 2{ }^{\circ} \mathrm{C}$; constant aeration. Mysidopsis juniae were fed the microcrustacean Artemia sp. enriched with fish oil (age: $72 \mathrm{~h}$ ) daily (ad libitum).

Three acute toxicity tests were carried out according to the ABNT protocol (ABNT 2011). Ten juveniles $M$. juniae (6-8 days old) were exposed in triplicate during 96 hours to four concentrations of diazepam, plus a negative control of filtered seawater. The organisms were fed daily with Artemia sp. (age: 48h) ad libitum. Every 24 hours the numbers of dead organisms were counted and removed from the replicate vials. Organisms were considered dead when immobilized during the five seconds after gentle mechanical stimulation. Physical and chemical parameters ( $\mathrm{pH}$, salinity and dissolved oxygen) were measured in the beginning and at the end of the experiment. The test validation criteria were based on the survival of the control, which should be over $90 \%$, and the sensitivity to zinc as reference substance of known toxicity (ABNT 2011). Tests carried out with the Zinc sulfate heptahydrate showed an average value of $\mathrm{LC}_{50}$ $0.37 \pm 0.01 \mathrm{mg} \cdot \mathrm{L}^{-1}$, which is within the acceptable limits and therefore validate our subsequent tests with DZP (Badaró-Pedroso et al. 2002, ABNT 2011, Figueirêdo et al. 2016).

The protocol for the chronic bioassay was followed as described by Figuêredo et al. (2016). Five M. juniae (age $\leq 24$ hours) were exposed to diazepam in quadruplicate for 7 days (final volume $250 \mathrm{~mL}$ ) without media renewal or aeration. For diazepam to present a half-life of 7.3 days, under light conditions, we decided not to renew the medium (Calisto et al. 2011). The tested concentrations were $0.125,0.25,0.5$ and $1 \mathrm{mg} \cdot \mathrm{L}^{-1}$ of diazepam in order to avoid mortality in accordance with the acute test results. The mysids were fed daily with Artemia sp. (age: 48h) following the proportion of 20 nauplii/mysid in the first 48 hours and 40 nauplii/mysid the next 5 days of exposure. Every 24 hours the number of dead organisms were recorded and removed from the vials. An organism was considered dead when it was immobilized during five seconds after gentle mechanical stimulation. Physical and chemical parameters ( $\mathrm{pH}$, salinity and dissolved oxygen) were measured at the beginning and at the end of the experiment. At the end of the experiment the body length and dry weight of all mysids from each exposure concentration and control were measured. The body length (from the head to the end of the last segment) was measured under a stereoscopic microscope as described by Figueirêdo et al. (2016). To obtain weight measurements, the mysids were dried at $60^{\circ} \mathrm{C}$ for 24 hours in an oven, and then weighed in an analytical balance $(0.00001 \mathrm{~g})$. The test validation criteria were based on the previous paper on the development of the short-term chronic toxicity test with $M$. juniae published by 
Figueirêdo et al. (2016), including survival in the control of over $80 \%$.

The lethal concentration for $50 \%$ of the population exposed $\left(\mathrm{LC}_{50}\right)$ was calculated using a Trimmed Spearman-Karber test (Hamilton et al. 1970). This is a non-parametric method wherein the $\mathrm{LC}_{50}$ and confidence interval are calculated using the mortality data observed in each concentration. In addition, the $\mathrm{LC}_{20}$ (i.e. lethal concentration of $20 \%$ of the population exposed) was estimated by the sigmoidal equation: $Y=\max /\left(1+(x /(100-x)) *\left(C_{\exp } / L C_{x}\right)^{b}\right)$, where $\mathrm{Y}$ is the response, $\mathrm{x}$ is the percent lethality (in this case 20\%), $C_{\exp }$ is the concentration exposure, $\mathrm{LC}_{\mathrm{x}}$ is the lethal concentration for $\mathrm{x} \%$ of the population, and $b$ is the slope.

$\mathrm{LC}_{50}$ and $\mathrm{LC}_{20}$ values were presented as means \pm standard deviation of three independent experiments. Length and dry weight data were checked for normal distributions (ShapiroWilk test) and analyzed by means \pm standard deviation to infer significant differences between treatments. Chronic data were subjected to a one-way ANOVA followed by a Dunnet test $(\alpha=0.05)$ to identify differences between the diazepam treatments and the control. The lowest observed effect concentration (LOEC) and non-observed effect concentration (NOEC) were then derived. The results were analyzed using the software GraphPad Prism 5.

\section{RESULTS AND DISCUSSION}

Currently, diazepam is found in aquatic matrices (effluent, rivers and lakes), ranging from 0.88 $\mu \mathrm{g} \cdot \mathrm{L}^{-1}$ to values below $1 \mathrm{ng} \cdot \mathrm{L}^{-1}$ (Calisto \& Esteves 2009). However, measured data for the marine environment is still scarce, which is also reflected in the limited toxicity data that are available, especially for sublethal endpoints for non-target organisms.
In this study we observed both acute and chronic effects on mysids when exposed to diazepam. Figure 1 presents the dose-response curve of the acute toxicity tests. The highest concentration that was used in the experiment induced an average of $76.6 \pm 1.96 \%$ mortality, while the obtained $\mathrm{LC}_{50}$ for diazepam was $3.7 \pm$ $0.5 \mathrm{mg} \cdot \mathrm{L}^{-1}$, and the LOEC was $5 \mathrm{mg} \cdot \mathrm{L}^{-1}$. Although significant effects were observed, it is unlikely that the same outcome would occur in the environment because the concentrations found in nature are below our tested range of $\mathrm{mg} \cdot \mathrm{L}^{-1}$ and may not negatively affect aquatic organisms (Calamari et al. 2003, Calisto \& Esteves 2009, Kosjek et al. 2012).

Table I summarizes toxicity data for freshwater, estuarine and marine organisms to DZP exposure. The $\mathrm{EC}_{50}$ (Effective Concentrations 50) or LC $_{50}$ values of diazepam for freshwater organisms are higher in comparison to mysids (Table I). The crustacean species Daphnia magna and D. pulex showed similar $24 \mathrm{~h}-\mathrm{EC}_{50}$ values, 14.1 $\mathrm{mg} \cdot \mathrm{L}^{-1}$ and $11.9 \mathrm{mg} \cdot \mathrm{L}^{-1}$, respectively (Calleja et al. 1994, Lilius et al. 1995), and the fish Gambusia holbrooki showed $96 \mathrm{~h}-\mathrm{LC}_{50}$ of $12.7 \mathrm{mg} \cdot \mathrm{L}^{-1}$ (Nunes et al. 2005). In general, freshwater species were less sensitive than mysids, and showed $L(E) C_{50}$ values 3 times (cladocera and fish), 28 times (fairy shrimp) and 2,700 times greater (rotifer) than mysids (Table I). However, in the cnidarian Hydra vulgaris polyp regeneration (chronic effect) was inhibited at $10 \mu \mathrm{g} \cdot \mathrm{L}^{-1}$ (Pascoe et al. 2009).

Among the marine species tested, mysids proved to be the most sensitive to diazepam for both approaches (Table I). Chronic toxicity testing showed significant mortality only at the highest tested concentration (1 mg. $\mathrm{L}^{-1}$, Fig. 2a), corresponding to $18.3 \pm 1.7 \%$ of the organisms (One Way ANOVA, Fx,y=14.7, $p<0.05$; Dunnet test, $\mathrm{p}<0.05)$. Furthermore, diazepam significantly affected both of the sublethal analyzed 


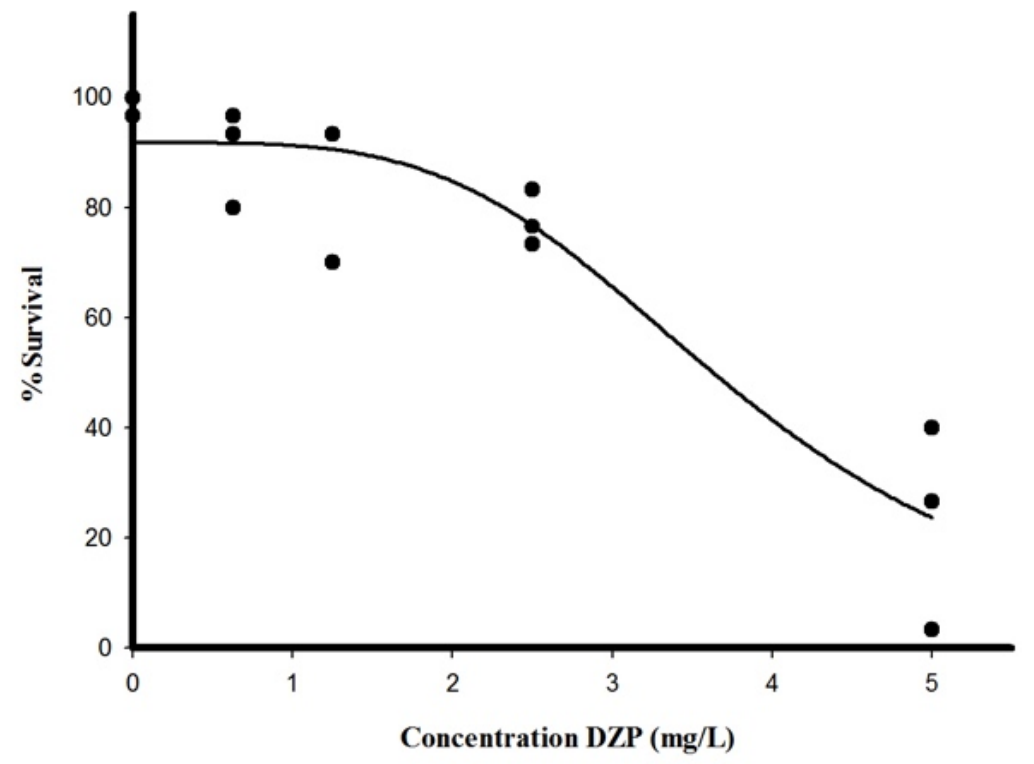

Figure 1. Survival of Mysidopsis juniae (\%) exposed for $96 \mathrm{~h}$ to diazepam in filtered seawater. Each data point corresponds to the survival mean value of each test/treatment carried out. The line corresponds to the Trimmed Spearman-Karber model applied to derive the $\mathrm{LC}_{50}$.

a

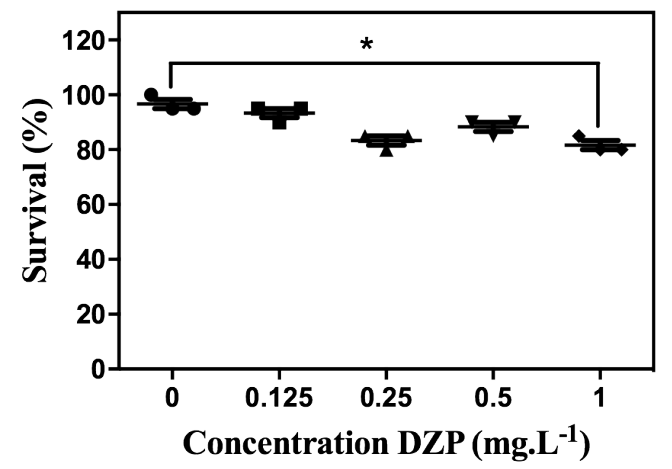

b

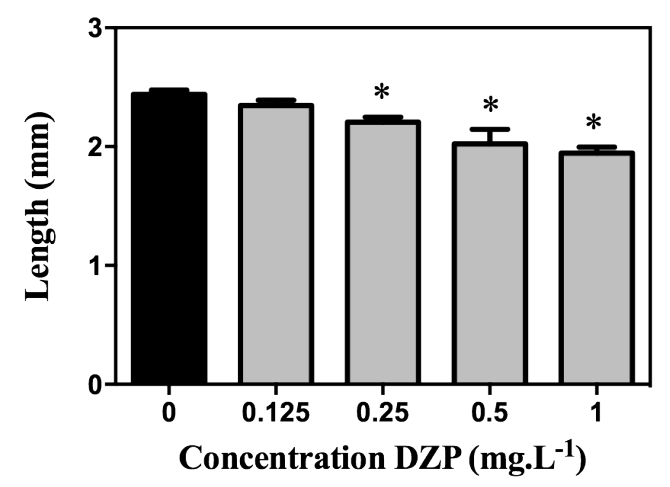

C

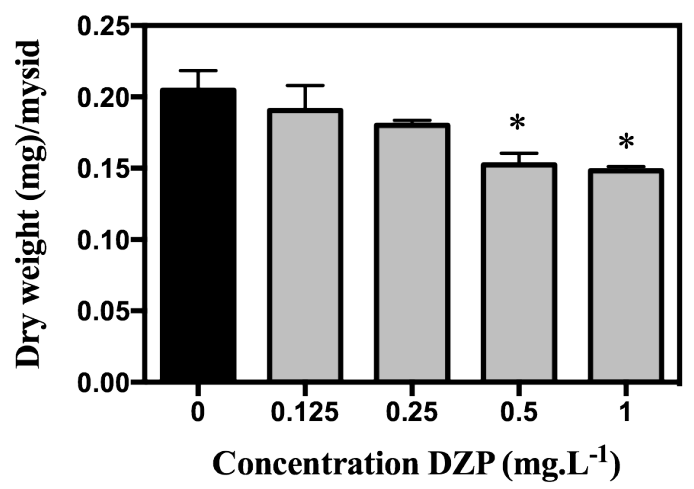

Figure 2. Effect of Diazepam on the survival (a), length (b) and dry weight (c) of the tropical mysid Mysidopsis juniae after seven days of exposure. Data correspond to mean \pm standard deviation from three independent experiments. $(*)$ Indicates significant difference $(p<0.05)$. 
Table I. Toxicity data of diazepam for non-target aquatic organisms. Endpoints are expressed as estimated $\mathrm{LC}_{50}$, $\mathrm{EC}_{50}, \mathrm{LC}_{20}$ or LOEC*.

\begin{tabular}{|c|c|c|c|c|}
\hline Test species & $\begin{array}{l}\text { Toxicity data } \\
\left(\mathrm{mg} \cdot \mathrm{L}^{-1}\right)\end{array}$ & Endpoint & & References \\
\hline \multicolumn{5}{|c|}{ Freshwater organisms } \\
\hline $\begin{array}{c}\text { Gambusia holbrooki } \\
\text { (fish) }\end{array}$ & 12.7 & Survival & $\mathrm{LC}_{50}$ & Nunes et. al. 2005 \\
\hline $\begin{array}{l}\text { Streptocephalus proboscideus } \\
\text { (crustacean) }\end{array}$ & 103.1 & Survival & $\mathrm{LC}_{50}$ & Calleja et. al. 1994 \\
\hline $\begin{array}{c}\text { Brachionus calyciflorus } \\
\text { (rotifer) }\end{array}$ & $>9,994.0$ & Survival & $\mathrm{LC}_{50}$ & Calleja et. al. 1994 \\
\hline Daphnia magna & 14.1 & Immobility & $\mathrm{EC}_{50}$ & Calleja et. al. 1994 \\
\hline (crustacean) & 4.3 & Immobility & $\mathrm{EC}_{50}$ & Lilius et. al. 1995 \\
\hline $\begin{array}{l}\text { Daphnia pulex } \\
\text { (crustacean) }\end{array}$ & 11.9 & Immobility & $\mathrm{EC}_{50}$ & Lilius et. al. 1995 \\
\hline $\begin{array}{l}\text { Hydra vulgaris } \\
\text { (cnidarian) }\end{array}$ & $10 \mu g \cdot L^{-1}$ & $\begin{array}{c}\text { Polyp } \\
\text { Regeneration }\end{array}$ & & Pascoe et al. 2009 \\
\hline \multicolumn{5}{|c|}{ Marine organisms } \\
\hline $\begin{array}{l}\text { Tetraselmis chuii } \\
\text { (algae) }\end{array}$ & 16.5 & Growth & $\mathrm{IC}_{50}$ & Nunes et. al. 2005 \\
\hline $\begin{array}{c}\text { Artemia parthenogenetica } \\
\text { (crustacean) }\end{array}$ & 12.2 & Survival & $\mathrm{LC}_{50}$ & Nunes et. al. 2005 \\
\hline $\begin{array}{l}\text { Artemia salina } \\
\text { (crustacean) }\end{array}$ & 65.5 & Survival & $\mathrm{LC}_{50}$ & Calleja et. al. 1994 \\
\hline Mysidopsis juniae & $\begin{array}{l}3.7 \\
5.0\end{array}$ & Survival & $\begin{array}{l}\mathrm{LC}_{50} \\
\mathrm{LOEC}\end{array}$ & Present study \\
\hline \multirow[t]{4}{*}{ (crustacean) } & 0.88 & Length & $\mathrm{LC}_{20}$ & Present study \\
\hline & 0.74 & Weight & $\mathrm{LC}_{20}$ & Present study \\
\hline & 0.25 & Length & LOEC & Present study \\
\hline & 0.5 & Weight & LOEC & Present study \\
\hline
\end{tabular}

* $\mathrm{LC}_{50}$ and $\mathrm{LC}_{20}$ - lethal concentration to $50 \%$ and $20 \%$ of organisms, respectively. $\mathrm{EC}_{50}$ - effect concentration to $50 \%$ of organisms. $\mathrm{IC}_{50}$ inhibition concentration to $50 \%$ of organism. LOEC - lowest observed effect concentration.

parameters, body length and dry weight, suggesting that although the chemical was not lethal it impaired the mysids' growth. Effects on M. juniae body length were observed at $0.25 \mathrm{mg} \cdot \mathrm{L}^{-1}$ (One Way ANOVA, Fx,y=28.9, p<0.05; Dunnett test, $p<0.05$; Fig. 2b), while dry weight was significantly affected at 0.5 and $1 \mathrm{mg} \cdot \mathrm{L}^{-1}$ (One Way ANOVA, $F x, y=5.1, \quad p<0.05$; Dunnett test, $p<0.05$; Fig. 2c). In the control, the average body length of $M$. juniae was $2.44 \pm 0.03 \mathrm{~mm}$, while in concentrations 0.25 , 0.5 and $1 \mathrm{mg} \cdot \mathrm{L}^{-1}$, the observed reduction was of $9.8 \%, 17.2 \%$ and $20.5 \%$, respectively. Dry weight was reduced by $25.5 \%$ and $27.6 \%$ at 0.5 and 1 $\mathrm{mg} \cdot \mathrm{L}^{-1}$, respectively. The estimated $\mathrm{EC}_{20}$ values were $0.88 \pm 0.11 \mathrm{mg} \cdot \mathrm{L}^{-1}$ for length and $0.73 \pm 0.43$ $\mathrm{mg} \cdot \mathrm{L}^{-1}$ for dry weight, suggesting an equivalent 
sensitivity for both parameters to DZP, but with a better reproducibility of the data when length was considered. In a previous work with this methodology, Figuerêdo et al. (2016) showed that the sensitivity of endpoints is hardly dependent on the chemical tested, while for zinc, dry weight was the most sensitive endpoint, for nickel, survival was the most sensitive parameter. Herein DZP affected mysids length and dry weight at concentrations 4 and 2 times lower, respectively, than it affects survival.

Several morphological, physiological or behavioral changes in aquatic organisms have been highlighted due to DZP exposure. Pascoe et al. (2009) kept polyps of the cnidarian Hydra vulgaris at concentration of $10 \mu \mathrm{g} \cdot \mathrm{L}^{-1}$ of diazepam for 72 hours and observed a reduction of their regenerative capacity. In addition, Lorenzi et al. (2016) observed a decrease in the number of eggs produced by the temperate freshwater fish Pimephales promelas when exposed to $10 \mu \mathrm{g} \cdot \mathrm{L}^{-1}$ of diazepam, although this was not statistically significant.

Fish have also shown some changes in behavioral responses. Gebauer et al. (2011) noted that the ability of Danio rerio to remain in groups was affected. Shoal cohesion suffered a decrease after 8 minutes of exposure to a concentration of $0.2 \mathrm{mg} \cdot \mathrm{L}^{-1}$ of diazepam. Moreover, diazepam increases the time of permanency of D. rerio (Gebauer et al. 2011) and Lepomis gibbosus (Brandão et al. 2013) in a light compartment. This type of behavior in the environment could facilitate the predation of these fish. As diazepam was designed to act on the human GABA receptors in the central nervous system, it is expected that it can affect other organisms such as crustaceans and fish that share the conserved GABA receptors. Despite morphological differences, crustaceans and fish both suffer from chronic effects of diazepam through its modification of ecologically important behaviors and potential to affect individual fitness (Brodin et al. 2014). In fishes, diazepam causes changes in swimming patterns (Bencan et al. 2009) and in crustaceans it increases the chances of being preyed upon (Rivetti et al. 2016). Diazepam may cause a decrease in the ability of mysids to capture food, which can be seen through a decrease in weight.

The toxicity of diazepam to non-target organisms may be related to the octanol-water partition $\left(\log _{\text {ow }}\right)$ coefficient value. The $\log K_{\text {ow }}$ coefficient value is a measure of lipophilicity for several compounds and reflects the interaction of the chemical compound with lipids (Lin and Sandler 1999). When a log $\mathrm{K}_{\text {ow }}$ is above 1.72, the chemical compound may interact with the fatty acid membranes, and potentially cross them (Kasim et al. 2004). Diazepam presents a logK $K_{\text {ow }}$ 2.85, thus indicating its lipophilic characteristics (Stuer-Lauridsen et al. 2000).

Looking at the toxicity data available for marine species (in particular the NOEC of $M$. juniae for length), and applying a potential safety factor of 100 (a value that is not overly conservative) we found a predicted no-effect concentration (PNEC) for diazepam of $2.5 \mu \mathrm{g} \cdot \mathrm{L}^{-1}$. When analyzing the value of the risk quotient (RQ = Measured Environmental Concentration / PNEC) based on the criteria recommended by Blair et al. (2013) it is evident that diazepam represents a low risk for the aquatic environment. However, it is important to consider the interaction with the sediment/sand fraction that can accumulate and be a source to the biota, since diazepam has a considerable affinity to these matrices (Lin et al., 2011).

We have shown that diazepam causes acute and sub-lethal effects in M. juniae. Although the concentrations that we tested are not often found under environmental conditions, it is interesting to assess whether ecologically 
relevant concentrations will be able to generate some kind of change in mysids, for example in biochemical or physiological parameters. In addition, the results motivate us to understand the effects of diazepam on other marine organisms, since studies are still scarce.

\section{Acknowledgments}

To Coordenação de Aperfeiçoamento de Pessoal de Nivel Superior (CAPES, PROEF. Proc 88881.157451/2017-01) for supporting english revision.

\section{REFERENCES}

ABNT - ASSOCIAÇÃO BRASILEIRA DE NORMAS TÉCNICAS. 2011. NBR15308: Ecotoxicologia aquática - Toxicidade Aguda - Método de Ensaio com Misidáceos (Crustacea). Associação Brasileira de Normas Técnicas, 20 p.

ANDREU V, GIMENO-GARCÍA E, PASCUAL JA, VAZQUES-ROIG P \& PICÓ Y. 2016. Presence of pharmaceuticals and heavy metals in the water of a Mediterranean coastal wetland: potential interactions and the influence of the environment. Sci Total Environ 540: 278-286.

BADARÓ-PEDROSO C, REYNIER MV \& PRÓSPERI VA. 2002. Testes de toxicidade aguda em misidáceos - ênfase nas espécies Mysidopsis juniae e Mysidium gracile (Crustacea: Mysidacea). In: Nascimento IA, Sousa ECPM \& Nipper M (Eds), Métodos em ecotoxicologia marinha: aplicações no Brasil. Artes Gráficas e Indústrias Ltda, p. 123-139.

BENCAN Z, SLEDGE D \& LEVIN ED. 2009. Buspirone, chlordiazepoxide and diazepam effects in a zebrafish model of anxiety. Pharmacol Biochem Behav 94: 75-80.

BIF MB, YUNES IS \& JUNIOR CR. 2013. Evaluation of mysids and sea urchins exposed to saxitoxins. Environ Toxicol Pharmacol 36: 819-825.

BLAIR BD, CRAGO JP, HEDMAN CJ \& KLAPER RD. 2013. Pharmaceuticals and personal care products found in the Great Lakes above concentrations of environmental concern. Chemosphere 93: 2116-2123.

BRANDÃO FP, RODRIGUES S, CASTRO BB, GONÇALVES F, ANTUNES SC \& NUNES B. 2013. Short-term effects of neuroactive pharmaceutical drugs on a fish species: biochemical and behavioural effects. Aquat Toxicol 144: 218-229.

BRODIN T, PIOVANO S, FICK J, KLAMINDER J, HEYNEN M \& JONSSON M. 2014. Ecological effects of pharmaceuticals in aquatic systems - impacts through behavioural alterations. Philos Trans R Soc Lond B Biol Sci 369: 1-10.

CALAMARI D, ZUCCATO E, CASTIGLIONIS, BAGNATI R \& FANELLI R. 2003. Strategic survey of therapeutic drugs in the rivers Po and Lambro in Nort.hern Italy. Environ Sci Technol 37: 1241-1248.

CALISTO V, DOMINGUES MRM \& ESTEVES VI. 2011. Photodegradation of psychiatric pharmaceuticals in aquatic environments - kinetics and photodegradation products. Water Res 45: 6097-6106.

CALLEJA MC, PERSOONE G \& GELADI P. 1994. Comparative acute toxicity of the first 50 multicentre evaluation of in vitro cytotoxicity chemicals to aquatic non-vertebrates. Arch Environ Contam Toxicol 26:69-78.

CALISTO V \& ESTEVES I. 2009. Psychiatric pharmaceuticals in the environment. Chemosphere 77:1257-1274.

COSTA CR, OLIVI P, BOTTA CMR \& ESPÍNDOLA ERG. 2008. A toxicidade em ambientes aquáticos: discussão e métodos de avaliação. Quim Nova 31:1820-1830.

DOMINGUES DF \& BERTOLETTI E. 2006. Seleção, Manutenção e Cultivo de Organismos Aquáticos. In: Zagatto PA \& Bertoletti E (Eds), Ecotoxicologia Aquática: princípios e aplicações. Rima, p. 153-184.

FENT K, WESTON AA \& CAMINADA D. 2006, Ecotoxicology of human pharmaceuticals. Aquat Toxicol 76: 122-159.

FERRER I, ZWEIGENBAUM JA \& THURMAN EM. 2010. Analysis of 70 Environmental Protection Agency priority pharmaceuticals in water by EPA Method 1694. J Chromatogr A 1217: 5674-5686.

FIGUEIRÊDO LP, NILIN J, SILVA AQ, DAMASCENO EP, LOUREIRO L \& COSTA-LOTUFO LV. 2015. Zinc and nickel binary mixtures act additively on the tropical mysid Mysidopsis juniae. Mar Freshwater Res 67: 301-308.

FIGUEIRÊDO LP, NILIN J, SILVA AQ, LOUREIRO S \& COSTA-LOTUFO LV. 2016. Development of a short-term chronic toxicity test with a tropical mysid. Mar Pollut Bull 106: 104-108.

GEBAUER DL, PAGNUSSAT N, PIATO AL, SCHAEFER IC, BONAN CD \& LARA DR. 2011. Effects of anxiolytics in zebrafish: Similarities and differences between benzodiazepines, buspirone and ethanol. Pharmacol Biochem Behavi 99: 480-486.

GURGEL PM, NAVONI JA, FERREIRA DM \& AMARAL VS. 2016. Ecotoxicological water assessment of an estuarine river from the Brazilian Northeast, potentially affected by industrial wastewater discharge. Sci Total Environ 572: 324-332. 
HAMILTON MA, RUSSO RC \& THURSTON RV. 1970. Trimmed Spearman-Karber Method for Estimating Median Lethal Concentrations in Toxicity Bioassays. Environ Sci Technol 11: 714-719.

HENRY TB, KWON JW, ARMBRUST KL \& BLACK MC. 2004. Acute and chronic toxicity of five selective serotonin reuptake inhibitors in Ceriodaphnia dubia. Environ Toxicol Chem 23: 2229-2233.

INCB - INTERNATIONAL NARCOTICS CONTROL BOARD. 2014. United Nations Publication. http:// www. incb.org/documents/Psychotropics/technicalpublications/2014/Web_SPA_2014.pdf Accessed 17 November 2014.

JONES OA, VOULVOILIS N \& LESTER JN. 2001. Human pharmaceuticals in the aquatic environmental - a review. Environ Technol 22: 1383-1384.

KASIM NA ET AL. 2004. Molecular properties of WHO essential drugs and provisional biopharmaceutical classification. Mol Pharmacol 1: 85-96.

KIM JW, ISHIBASHI H, YAMAUCHI R, ICHIKAWA N, TAKAO Y, HIRANO M, KOGA M \& ARIZONO K. 2009. Acute toxicity of pharmaceutical and personal care products on freshwater crustacean (Thamnocephalus platyurus) and fish (Oryzias latipes). J Toxicol Sci 34:227-232.

KOSJEK T, PERKO S, ZUPANC M, HREN MZ, DRAGICEVIC TL, ZIGON D, KOMPARE B \& HEATH E. 2012. Environmental occurrence, fate and transformation of benzodiazepines in water treatment. Water Res 46: 355-368.

KUSTER M, AZEVEDO DA, ALDA MJL, NETO FRA \& BARCELÓ D. 2009. Analysis of phytoestrogens, progestogens and estrogens in environmental Waters from Rio de Janeiro (Brazil). Environ Int 35: 997-1003.

LILIUS H, HÄSTBACKA T \& ISOMAA B. 1995. A comparison of the toxicity of 30 reference chemicals to Daphnia magna and Daphnia pulex. Environ Toxicol Chem 14: 2085-2088.

LIN, K, BONDARENKO S \& GAN JJ. 2011. Sorption and persistence of wastewater-borne psychoactive and antilipidemic drugs in soils. J Soil Sediment 11: 1363.

LIN ST \& SANDELER SI. 1999. Prediction of octanol water partition coefficients using a group contribution solvation model. Ind Eng Chem Res 38: 4081-4091.

LÓPEZ-SERNA R, PETROVIC M \& BARCELÓ D. 2012. Direct analysis of pharmaceuticals, their metabolites and transformation products in environmental waters using on-line Turboflow chromatography-liquid chromatography-tandem mass spectrometry. J Chromatogr A 1252: 115-129.
LORENZIV, CHOER \& SCHLENKD. 2016. Effects of environmental exposure to diazepam on the reproductive behavior of fathead minnow, Pimephales promelas. Environ Toxicol 31: $561-568$.

MCKERNAN RM ET AL. 2000. Sedative but not anxiolytic properties of benzodiazepines are mediated by the GABA(A) receptor a1 subtype. Nat Neurosci 3: 587-592.

NILIN J, SANTOS AAO \& NASCIMENTO MKS. 2019. Ecotoxicology assay for the evaluation of environmental water quality in a tropical urban estuary. An Acad Bras Cienc 91: e20180232.

NUNES B, CARVALHO F \& GUILHERMINO L. 2005. Acute toxicity of widely used pharmaceuticals in aquatic species: Gambusia holbrooki, Artemia parthenogenetica and Tetraselmis chuii. Ecotoxicol Environ Saf 61: 413-419.

OBID - OBSERVATÓRIO BRASILEIRO DE INFORMAÇÕES SOBRE DROGAS. 2007. http://www.obid.senad.gov.br/obid. Acesso em 14 de novembro de 2014.

PASCOE D, KARNTANUT W \& MÜLLER CT. 2009. DO pharmaceuticals affect freshwater invertebrates? A study with the cnidarians Hydra vulgaris. Chemosphere 51: 521-528.

PATROLECCO L, ADEMOLLO L, GRENNI P, TOLOMEI A, CARACCIOLO AB \& CAPRI S. 2013. Simultaneous determination of human pharmaceuticals in water samples by solid phase extraction and HPLC with UV-fluorescence detection. Microchem J 107: 165-171.

SILVA AQ, NILIN J, SANTAELLA ST \& BONILLA OH. 2017. Ecotoxicological and physicochemical evaluation of an effluent of a shrimp farm located in Northeastern Brazil. Pan-Am J Aquat Sci 12: 263-272.

QUINN B, GAGNÈ F \& BLAISE C. 2008. An investigation into the acute and chronic toxicity of eleven pharmaceuticals (and their solvents) found in wastewater effluent on the cnidarian, Hydra attenuata. Sci Total Environ 389: 306-314.

RODRÍGUEZ-NAVAS, C, BJÖRKLUND, E, BAK, SA, HANSEN, M, KROGH, KA, MAYA, F, FORTEZA, R \& CERDÀ, V. 2013. Pollution Pathways of Pharmaceutical Residues in the Aquatic Environment on the Island of Mallorca, Spain. Arch Environ Contam Toxicol 65: 56-66.

REDSHAW CH, COOKE MP, TALBOT HM, MCGRATH S \& ROWLAND SJ. 2008. Low biodegradability of fluoxetine $\mathrm{HCl}$, diazepam and their human metabolites in sewage sludgeamended soil. J Soil Sediment 8: 217-230.

RIVETTI C, CAMPOS B \& BARATA C. 2016. Low environmental levels of neuro-active pharmaceuticals alter phototactic 
behaviour and reproduction in Daphnia magna. Aquat Toxicol 170: 289-296.

SHEPHARD RA. 1986. Neurotransmitters, Anxiety and Benzodiazepines: a behavioral review. Neurosci Biobehav Rev 10: 449-461.

STUER-LAURIDSEN F, BIRKVED M, HANSEN LP, LÜTZHO HCH \& HALLING-SORENSEN B. 2000. Environmental risk assessment of human pharmaceuticals in Denmark after normal therapeutic use. Chemosphere 40: 783-793.

SUÁREZ S, CARBALLA M, OMIL F \& LEMA JM. 2008. How are pharmaceutical and personal care products (PPCPS) removed from urban wastewaters? Environ Sci Technol 7: $125-138$.

VEN KV, DONGEN WV, MAES BUW, ESMANS EL, BLUST $R$ \& COEN WMD. 2004. Determination of diazepam in aquatic samples by capillary liquid chromatographyelectrospray tandem mass spectrometry. Chemosphere 57: 967-973.

VERSLYCKE TA, FOCKEDEY N, MCKENNEY CL, ROAST SD, JONES MB, MEES I \& JANSSEN CR. 2004. Mysid crustaceans as potential test organisms for the evaluation of environmental endocrine disruption: a review. Environ Toxicol 23: 1219-1234.

YUAN S, JIANG X, XIA X, ZHANG H \& ZHENG S. 2013. Detection, occurrence and fate of 22 psychiatric pharmaceuticals in psychiatric hospital and municipal wastewater treatment plants in Beijing, China. Chemosphere 90: 2520-2525.

ZUCCATO E, CALAMARI D, NATANGELO M \& FANELLI R. 2000. Presence of therapeutic drugs in the environment. Lancet 355: 1789-1790

\section{How to cite}

SILVA AQ, NILIN J, LOUREIRO S \& COSTA-LOTUFO LV. 2020. Acute and chronic toxicity of the benzodiazepine diazepam to the tropical crustacean Mysidopsis juniae. An Acad Bras Cienc 92: e20180595. DOI 10.1590/0001-3765202020180595.

Manuscript received on June 12, 2018; accepted for publication on November 6, 2018

ALLYSON Q. DA SILVA ${ }^{1}$

https://orcid.org/0000-0002-7756-1426

\section{JEAMYLLE NILIN ${ }^{2}$}

https://orcid.org/0000-0002-1636-4541

\section{SUSANA LOUREIRO}

https://orcid.org/0000-0002-5393-9623

\section{LETICIA V. COSTA-LOTUFO ${ }^{1,4}$}

https://orcid.org/0000-0003-1861-5153

1'Instituto de Ciências do Mar/LABOMAR, Universidade Federal do Ceará, Av. da Abolição 3207, Bairro Meireles, 60165-081 Fortaleza, CE, Brazil

${ }^{2}$ Instituto de Biologia, Universidade Federal de Uberlândia, Rua Ceará, s/n, Bloco 2D, Bairro Umuarama, 38405-302 Uberlândia, MG, Brazil

${ }^{3}$ Department of Biology and CESAM, University of Aveiro, 3810-193, Aveiro, Portugal

${ }^{4}$ Departamento de Farmacologia, Instituto de Ciências Biomédicas, Universidade de São Paulo, Av. Lineu Prestes, 1524, Bairro Butantã, 05508-900, São Paulo, SP, Brazil

Correspondence to: Jeamylle Nilin, Leticia V. Costa-Lotufo E-mail:nilin@ufu.br, costalotufo@usp.br

\section{Author contributions}

Allyson Silva: Methodology, Formal analysis, Investigation, Writing - original draft. Jeamylle Nilin: Methodology, Formal analysis, Investigation, Writing - review \& editing, Visualization. Susana Loureiro: Writing - review \& editing. Letícia Costa-Lotufo: Conceptualization, Writing - review \& editing, Supervision.

\section{(cc) BY}

